\title{
ENTREVISTA
}

\section{Acerca de Karl Marx em Sobre a questão judaica}

\author{
Vitor Bartoletti Sartori ${ }^{1}$ \\ RESGATANDO OS CLÁSSICOS ${ }^{2}$ : Luís Eduardo da Rocha Maia Fernandes ${ }^{3}$ | Poliana \\ Mendes Cavalheiro ${ }^{4}$ Antonio Ugá Neto ${ }^{5}$
}

Como citar esta entrevista: SARTORI, Vitor Batoletti. Acerca de Karl Marx em Sobre a questão judaica. Resgatando os clássicos. Revista de Ciências do Estado. Belo Horizonte: v. 5, n. 1, e23740. ISSN: 2525-8036.

Realizada em 27.05.2020

Publicada em 30.06.2020

Resgatando Clássicos é uma iniciativa que pretende divulgar grandes obras do pensamento social crítico através de entrevistas realizadas pelo canal do Youtube Antonio Ugá. A Revista de Ciências do Estado foi convidada a publicar a entrevista concedida por Vitor Bartoletti Sartori, professor Doutor da Faculdade de Direito da Universidade Federal de Minas Gerais.

Karl Marx, ao lado de Friedrich Engels, construiu a mais importante produção teórica para a análise da gênese, desenvolvimento e crise da sociedade burguesa. Nascido na região da Renânia na Prússia em 1818, atual Alemanha, Marx inicia seus estudos no Direito, mas acaba se formando em Filosofia em 1841. Em "Sobre a Questão Judaica" ou, simplesmente, "A Questão Judaica", Marx realiza uma crítica radical a um texto sobre o tema publicado por

\footnotetext{
${ }^{1}$ Vitor Bartoletti Sartori é professor da faculdade de Direito da Universidade Federal de Minas Gerais. Email: vitorbsartori@gmail.com.

${ }^{2}$ Resgatando Clássicos é uma modesta iniciativa, em surgida em tempos difíceis de quarentena, que pretende divulgar grades obras do pensamento social crítico, organizada por Luís Fernandes, Poliana Cavalheiro e Antonio Ugá, com entrevistas disponibilizadas no canal do Youtube Antonio Ugá <www.youtube.com/antoniouga $>$.

${ }^{3}$ Luís Eduardo da Rocha Maia Fernandes é historiador formado pela UFF e possui mestrado em História pela mesma instituição (2016). Atualmente é doutorando no programa da ESS da UFRJ e professor substituto de História do IFSP, campus Cubatão. E-mail: luisedumfernandes@ gmail.com.

${ }^{4}$ Poliana Mendes Cavalheiro é economista graduada em Ciências Econômicas pela UFS. Mestranda em Desenvolvimento Econômico pela Universidade Federal de Alfenas (UNIFAL). E-mail: poli.mendes.eps@gmail.com.

${ }_{5}^{5}$ Antonio Ugá Neto é advogado, com bacharelado em Direito pela FDA/UFAL, possui pós-graduação em Direito Processual na UNIT Alagoas e é mestrando em Serviço Social no PPGSS-UFAL. Autor de capítulo do livro "Temas de Crítica ao Direito" (organização Adriano Nascimento). Membro do Grupo de Pesquisa Estado, Direito e Capitalismo Dependente. E-mail: antoniouganeto@gmail.com.
} 
Bruno Bauer, representando uma das obras, ao lado de A Sagrada Família e Ideologia Alemã, que marcam a ruptura de Marx e Engels com os Jovens Hegelianos.

RESGATANDO OS CLÁSSICOS: Primeiramente, você pode contextualizar a trajetória política e intelectual de Karl Marx até 1843, quando escreveu o texto que estamos debatendo?

VITOR: Contrariamente ao que alguns podem acreditar, a questão não pode ser reduzida a um acerto de contas com Hegel e com os hegelianos, que teria se dado em algum momento pontual do percurso de nosso autor. Basta pensar na leitura sui generis que Marx realiza dos pensadores gregos a partir de Hegel em sua tese doutoral de 1841 para que percebamos que questões aparentemente menores - que somente poderiam ser notadas por alguém de conhecimento enciclopédico como nosso autor - poderiam ter uma influência decisiva. No caso, trata-se da constatação da ausência de um tratamento cuidadoso dos autores antigos, como Demócrito e Epicuro por parte do autor da Fenomenologia do espírito. Se olharmos para este mesmo texto, de 1841, também percebemos que existe, desde cedo, uma denúncia do sistema hegeliano. Em A diferença entre a filosofia da natureza de Demócrito e de Epicuro, diz-se que a maneira de se relacionar com a filosofia de Hegel precisaria ser reflexiva, e não imediata. Ou seja, Marx nunca foi propriamente um hegeliano dogmático no campo de seu caminho filosófico.

E, por isto, desde o início, é preciso que percebamos que o entendimento de seu pensamento precisa partir da imanência das determinações de seus textos. Ficar procurando correspondências entre a Lógica, a Fenomenologia e Marx, por isto, não só é equivocado; consiste em um erro grave. E que traz certas imputações à leitura da obra marxiana, imputações estas que podem render muitos debates, mas que, em parte considerável, têm por resultado a ausência de análise das obras de Marx, principalmente aquelas da década de 1840, em que se formará o pensamento propriamente marxiano.

Podemos dizer isto, dentre outras razões, porque a extensão de temas tratados por Marx já em sua carta de 1837 é enorme, e dá uma dimensão das questões que marcam o pensamento marxiano em sua gênese. Na carta, Marx menciona influências de Fichte, fala de estética, trata de planos de desenvolver um sistema do Direito, por exemplo. Porém, quanto ao último ponto, já deixa clara a sua postura radicalmente avessa à doutrina jurídica tradicional, estudada nos cursos de "jurisprudência", que Marx frequentou, mas não terminou, transferindo-se para a filosofia. Destaco este ponto porque nosso autor, na década de 1840, e em especial na Gazeta renana, em 1842, debaterá muitos temas que são permeados pelo 
Direito. E, sobre isto, sempre, a postura de Marx é crítica quanto à mera operacionalização da esfera jurídica, a qual ele questiona e seu funcionamento desde os seus primeiros escritos, mas que, depois de 1843, passará a criticar como tal.

Tal processo formativo traz como uma de suas marcas a crítica à doutrina jurídica, e a predileção pelos aspectos filosóficos. Com isto, Marx, que diz já haver lido Hegel do começo ao fim já em 1837, é levado à tematização hegeliana do Estado e do Direito; porém, como já dissemos, há nisto um traço único e original. $\mathrm{O}$ hegelianismo pairava no ar, mas isto ocorria em um contexto bastante preciso e que nosso autor chamou posteriormente de miséria alemã. Tal contexto vem a ser central em alguns sentidos para a compreensão deste importante texto que aqui tratamos. Os alemães apareciam como contemporâneos teóricos daquilo de mais avançado do desenvolvimento burguês; porém, sequer a unificação da Alemanha enquanto país estava consolidada. Para que relacionemos isto ao processo formativo marxiano: Marx estudou um Direito fortemente marcado pelo localismo, e por uma estrutura burocrática e estatal engendrada pelos privilégios; com isto, veio a procurar em Hegel - um representante do Estado moderno - o parâmetro contra a irracionalidade da realidade da sociedade e do Estados alemães. Isto marca seus textos da Gazeta renana, bem como os debates jornalísticos democráticos da época, dos quais nosso autor participava também como editor da gazeta mencionada.

Como não poderia deixar de ser, isto se dá de modo bastante conflituoso, teórica e praticamente. No campo prático, a Gazeta via-se constantemente ameaçada, chegando a ser fechada pelo governo. Censura, poderes locais, falta de unidade entre as dietas e o poder central, privilégios dos grandes proprietários rurais eram algo que marcava a vida cotidiana de Marx, e contra a qual desde cedo se insurgiu. Com isto, a defesa hegeliana da burocracia que figuraria como classe universal - e do Estado redunda no apoio marxiano ao Estado racional e ao Direito universal. Posteriormente, na Crítica à filosofia do Direito de Hegel, do começo de 1843, nosso autor vem a defender a democracia contra a monarquia, procurando colocar explicitamente a sociedade como o sujeito, e não o predicado, do Estado. Neste contexto, devemos pontuar primeiramente que a posição hegeliana segundo a qual seria possível reconciliar as contradições da sociedade civil-burguesa na figura do Estado é defendida por nosso autor até o começo de 1843. Isto porém, depende de uma leitura bastante própria e "reflexiva" de Hegel. Em segundo lugar, tem-se o aporte mais "metodológico" da questão, que remete à possibilidade da realidade se adequar ao conceito, em outras palavras, à eventual racionalidade do real, como diz Hegel na Filosofia do Direito. Ou seja, de um lado, 
há a aposta dos hegelianos e dos democratas no desenvolvimento do Estado moderno na Alemanha; doutro, tem-se a crença de que a base desta Estado - a própria sociedade capitalista - pode ser racional.

O contexto filosófico de Marx, pois, é marcado pelo hegelianismo, mas também está relacionado com a busca pela racionalidade de uma sociedade que seria vista por nosso autor posteriormente - já em Sobre a questão judaica, mas também em Crítica à filosofia do Direito de Hegel, introdução - como essencialmente irracional. Lembremos que, Hegel enxerga tal sociedade como uma espécie de espetáculo de miséria e devassidão; porém, o ator da Fenomenologia enxerga o Estado como capaz de elevar as oposições da sociedade civilburguesa a um patamar superior, por meio do qual elas seriam reconciliadas com um desenvolvimento plenamente racional e universal. O que queremos dizer com isto é: o embate filosófico no qual se colocava Marx tinha uma dimensão essencialmente política e ligada à defesa tanto do Estado moderno quanto de uma sociedade não mais regida pelo privilégio. Tal solo é aquele em que, sem a compreensão da natureza do capitalismo, não há como progredir. Como nos lembra constantemente o marxista húngaro György Lukács, o próprio Hegel estudou economia política, principalmente Stuart e Smith. E, devemos acrescentar que Marx toma contato com a economia política na década de 1840, em grande parte devido à influência de Engels. Se nosso autor diz depois que tomou contato com os interesses materiais como editor da Gazeta renana - basta lembrarmos dos temas discutidos no artigo sobre o furto da lenha - devemos destacar que entre 1843 e 1844 nosso autor começará um trabalho que levará com seriedade durante toda a sua vida, a crítica da economia política.

O “jovem Marx" insere-se neste debate, que, claro, tem uma função social concreta na própria realidade. E, sobre tal ponto, vale lembrar a atuação marxiana no periódico democrático Gazeta Renana, já mencionado por nós e do qual foi editor. Por mais que os eventos que tenhamos citados sejam anteriores ao texto que aqui pretendemos analisar (que é do final de 1843), há de se perceber que o pano de fundo do atraso alemão, e, mais precisamente, da miséria alemã, é essencial para eles, tal qual é em Sobre a questão judaica. A análise dos textos marxianos da Gazeta Renana demonstra em nosso autor a existência de uma perspectiva fortemente apegada à politicidade; para nosso autor, a resolução das vicissitudes do Direito, da sociedade e ligadas aos interesses materiais (que já emergem, por exemplo, no mencionado artigo sobre o furto da lenha) estaria na política e na separação entre esta e a religião. E, assim, nesta época, emerge parte substancial da temática do texto que aqui nos propomos a analisar. Para que sejamos explícitos: o modo sui generis pelo qual Marx lida com o pensamento hegeliano precisa ser compreendido pela leitura atenta de sua tese 
doutoral; seus interesses, que redundam em um envolvimento democrático à época, já aparecem em sua carta a seu pai e se explicitam na Gazeta Renana.

Nesta última, os diretos do homem - justamente vistos como essenciais ao Estado político por Bruno Bauer - são vistos como de enorme relevo pelo próprio Marx, em oposição à "animalidade do espírito" da feudalidade, ainda presentes na Alemanha. E, assim, Marx apoia-se em um conceito hegeliano de Estado em sua crítica - ainda idealista e marcada pela defesa da política e do Direito - ao Direito, ao Estado e à sociedade alemãs. Marx, aqui, ainda não critica a sociedade civil-burguesa como tal, nem o Estado e o Direito como tais. Ele busca que a efetividade deles se adeque ao seu conceito, procurando uma relação racional entre estas esferas. E, assim, a posição reflexiva de Marx diante da filosofia hegeliana, bem como a configuração específica da formação social alemã o levam a uma crítica decidida da realidade alemão; e isto, até certo ponto, é o oposto do que ocorre com a racionalização do real hegeliana. Nesta última, a sociedade civil-burguesa aparece com feições um tanto quanto germânicas, por exemplo, na defesa do autor da Filosofia do Direito das corporações e da monarquia. Diante dos privilégios vigentes em certas atividades na Alemanha (os judeus, como seu pai, por exemplo, não podiam exercer advocacia), Marx enxerga na sociedade alemã o oposto daquilo que poderia ser visto como adequado ao conceito de razão. Ele, deste modo, também defende uma Estado racional que se coloca fortemente contra o privilégio e explicitamente contra a ligação entre Direito, Estado e religião. E, com isto, coloca-se explicitamente contra o hegelianismo conservador. Tal postura, por sua vez, é radicalizada na Crítica à filosofia do Direito de Hegel, do começo de 1843, em que nosso autor traz a superação da oposição entre indivíduo e gênero na figura política da democracia. Tais textos possuem muitos meandros e acredito ser de grande importância o estudo detido deles.

O texto imediatamente anterior à Sobre a questão judaica, a Crítica à filosofia do Direito de Hegel, portanto, traz ainda mais avanços de Marx no sentido de uma crítica decidida a Hegel. Isto, porém, traz consigo um importante elemento no que diz respeito ao modo de se proceder diante do real, e à maneira pela qual se concatenam aquilo que, em $O$ capital, nosso autor chamaria de modo de pesquisa e de exposição. Aqui, há, de um lado, uma crítica ao pensamento especulativo, ligado à inversão entre sujeito e predicado; doutro lado, vê-se como real sujeito do processo social, não mais o Estado, como em Hegel, mas a sociedade civil-burguesa. Tais passos seriam decisivos para nosso autor.

Com eles, um pouco antes do texto que aqui analisamos, nosso autor vem a defender uma espécie de sociedade política, que superaria a oposição entre sociedade civil-burguesa e 
Estado. Marx procura na democracia a forma de governo em que a política não apareceria mais estranhada do e contraposta ao corpo da sociedade. E, assim, ainda se liga a uma defesa da politicidade, mas já critica a especulação, uma abordagem que chamaria de teológica da filosofia, bem como a figura do Estado. Levanto todas estas questões para destacar que a posição de Sobre a questão judaica é radicalmente diferente destas todas: não mais a defesa do Estado moderno laico e dos Direitos humanos, mas a crítica à religiosidade e à determinação ontopositiva da politicidade. Ou seja, o texto que aqui nos propomos a abordar marca - juntamente com Crítica à filosofia do Direito de Hegel, introdução - a conformação de elementos essenciais a todo o pensamento marxiano: a crítica à especulação (e com ela, da religião), da política (com ela, do Estado) e da sociedade civil-burguesa (o que redundaria posteriormente no desenvolvimento de uma crítica à economia política. Com isto, a solução da miséria alemã não passaria tanto pela efetivação do Estado moderno e pela superação do privilégio no Direito humano; ter-se-ia, no limite, a necessidade de superação da base da própria religião, do Direito e do Estado. E esta base, dizia nosso autor, estaria justamente na moderna sociedade civil-burguesa. Marx, que ainda desenvolveria todos estes pontos durante sua vida, coloca-se definitivamente sobre seus próprios pés. E acredito que seja importante a percepção deste percurso porque ele deixa claro como que o desenvolvimento de nosso autor é bastante sui generis e relaciona-se com seu posicionamento diante da realidade alemã.

\section{RESGATANDO OS CLÁSSICOS: Sobre a questão judaica é uma crítica de Marx a artigo publicado por Bruno Bauer, vocês podem tratar da relação de Marx e a ruptura de Marx com os Jovens Hegelianos?}

VITOR: Este tema não é nada simples, e por diversas razões. Primeiramente, porque não há propriamente um "movimento" dos "velhos" e dos "novos" ou da "direita" e da "esquerda" neohegeliana. Pode-se dizer que a problematização hegeliana da relação entre sociedade civil-burguesa e Estado (justamente um dos grandes temas de Sobre a questão judaica) pairava no ar. E isto não se dava simplesmente devido à superioridade do hegelianismo, mas devido às condições especificamente alemãs, que faziam com que, como disse Marx, os alemães fossem contemporâneos teóricos dos franceses, dos ingleses e dos americanos, mas estivessem atrasados social e politicamente. A tematização neohegeliana, que girou em torno do Estado moderno e de sua relação com a religião e o Direito, colocavase sobre o solo do atraso e da miséria alemãs.

Ou seja, outra dificuldade ao tratar do tema diz respeito ao fato de que, com isto, o universalismo defendido pela emancipação política vinda com as revoluções políticas 
burguesas aparecia na figura do "Estado político" e na generidade dos "direitos do homem" aos filósofos alemães. Mas não era essa a realidade na sociedade alemã.

Para uma perspectiva idealista, como aquela defendida por aqueles que se apegavam à filosofia de Hegel, a Alemanha não parecia ser consciente de suas próprias possibilidades. E, deste modo, seria preciso remeter ao movimento da autoconsciência; para Marx, por outro lado, a partir de 1843, tal solução seria nada menos que absurda: para a sagrada família de Bauer, parecia ser possível superar uma situação real por meio da autoconsciência de uma reconciliação imaginária (mais precisamente, aquela entre sociedade civil-burguesa - em Sobre a questão judaica, representada pelo bourgeois - e o Estado. Neste último, o cidadão teria seu locus natural, em meio à universalidade dos direitos do homem. Ou seja, aos autores criticados por Marx, parecia se tratar de fazer com que a compressão falsa de Hegel sobre o Estado e o capitalismo se tornasse verdadeira. Mas, de fato, ela era irreal desde o início. E o mesmo vale para o modo pelo qual o estranhamento religioso aparece superado em Hegel, e nos neohegelianos: com a permanência da religião e, principalmente, da religiosidade, mas no âmbito privado. Marx, a partir de então, compreende que a oposição entre sociedade e Estado é irreconciliável. A resolução das questões religiosas também seria impossível neste solo.

Destaco estes últimos aspectos porque é essencial ao posicionamento de Marx contra a ideologia alemã. Diz o nosso autor que, em verdade, na esteira do desenvolvimento da sociedade civil-burguesa, a existência religiosa do Estado é superada, mas a religiosidade se coloca na própria sociedade. E, com isto, a existência de potências estranhadas permanece como uma espécie de segunda natureza; para Bauer e consortes, a contraposição entre céu e terra, bem como entre o Estado e a sociedade civil-burguesa parece trazer a chave para a resolução das questões. Porém, segundo nosso autor, tal qual Lutero e o protestantismo teriam dado novo ímpeto à religião, a emancipação política daria nova força aos vícios da sociedade capitalista. A religião mais mundana do protestantismo parecia se contrapor à existência da miséria da terra do mesmo modo que os direitos do homem pareciam se voltar contra a "miséria e devassidão" (Hegel) da sociedade civil-burguesa. E, segundo Marx, isto faria com que fosse necessário rumar da crítica da religião (realizada pelos mais radicais dos neohegelianos, como Feuerbach) à crítica da política e dos fundamentos da religião. Trata-se, em verdade, da crítica da sociedade civil-burguesa, e, com isto, do capitalismo. O embate de nosso autor com os neohegelianos, portanto, redunda em uma crítica à política e às suas bases, colocadas nas condições e nos pressupostos da sociedade civil-burguesa; e sempre é bom lembrar que, posteriormente, no prefácio de 1859, Marx diria que a anatomia desta sociedade 
estaria na economia política. A crítica à especulação, à política e à economia política, portanto, como bem destacou o filósofo brasileiro José Chasin, são constitutivas do pensamento propriamente marxiano. E, em minha opinião, elas permanecem em toda a sua teorização.

A ruptura com Hegel e com os neohegelianos se coloca neste contexto. A partir da crítica destas posições idealistas, em suas diversas figuras, - que nosso autor chamaria ironicamente de "crítica da crítica crítica" - Marx procura dar uma base mundana a estas questões, que apareciam de modo especulativo à ideologia alemã. $\mathrm{O}$ primeiro pressuposto para isto seria a crítica da religião, destacando-se que não há qualquer potência ontológica transcendente que traz os homens como predicados de uma Sujeito hipostasiado.

Com isto, notamos que no embate com os neohegelianos, Marx realiza uma crítica decidida tanto à religião, quanto à política. Ao contrário dos mais radicais deles, como Bruno Bauer, ele deixa de trazer como solução para a miséria alemã a universalidade do Estado moderno, dos Direitos humanos, enfim, da política. Também, em debate com a teoria de Feuerbach, realiza uma crítica à religião e ao estranhamento religioso.

E o mesmo que foi dito antes sobre a relação de Marx com Hegel vale para sua relação com Feuerbach: nosso autor dialoga com o escritor da Essência do cristianismo, mas sem se apropriar de modo acrítico de seu pensamento (que passaria por uma crítica decidida em A ideologia alemã). Se é verdade que Marx concorda com a posição de Feuerbach segundo a qual o homem cria a religião, mas a religião (e deus) não cria o homem, sua crítica à religião já está relacionada ao questionamento da base real da religião. Com isto, como já dito, vai-se da crítica à religião até a crítica à política e desta à compreensão radical dos pressupostos da economia política e da sociabilidade burguesa.

No que é preciso que se destaque um aspecto que é de enorme relevo para a posição marxiana: o neohegelianismo, bem como a burguesia democrática alemã, em verdade, procuravam tornar efetivo algo que já era uma realidade. Segundo Marx, não se tinha tanto a emancipação política, o Estado político, os direitos do homem como algo que ainda precisava ser realizado. E verdade, a realidade destes conceitos estava na própria realidade efetiva da sociabilidade burguesa. Não seria possível medir a existência mundana pela ideia celeste, e também não se poderia de modo algum trazer como medida da sociedade o cidadão universal. Para nosso autor, ao contrário do que se dava para aqueles que permaneciam presos à concepção hegeliana, a forma de universalidade dos direitos do homem é efetiva no particularismo da sociedade civil-burguesa. O cidadão, por sua vez, não se realiza nas ideias de Rousseau, mas no modo extremamente contraditório pelo qual a Revolução francesa 
realiza os interesses da burguesia de uma forma plebeia, como diria depois nosso autor na Nova Gazeta Renana, em 1848.

Ou seja, não se tem ideias a realizar na realidade. Esta última é o critério da primeira, e não o oposto. Apegar-se à oposição entre ideia e realidade seria cair na ilusão especulativa, invertendo sujeito e predicado e tomando o real como uma espécie de exteriorização mais ou menos perfeita da ideia. O combate à ideologia alemã, à miséria alemã e à posição neohegeliana, portanto, levam Marx ao materialismo. Claro, este processo é bastante cheio de meandros; porém, acredito que Sobre a questão judaica traz aspectos decisivos acerca dele, e do modo pelo qual desenvolve-se a crítica à política.

Justamente esta contraposição entre a ideia de Estado, de sociedade e de razão de um lado, e a efetividade de outro - algo que, de certo modo, arrepiaria o próprio Hegel - passa a ser central para aquilo que Marx e Engels chamariam de ideologia alemã, e que é criticado na obra homônima, bem como na Sagrada família, que traz uma crítica contundente, elaborada juntamente com Engels, da filosofia neohegeliana.

Podemos dizer que a partir de Sobre a questão judaica, Marx passa de uma tarefa negativa - a crítica da política e da religião - à explicação das bases sobre as quais se colocam estas duas esferas. Aponto estes aspectos porque, sem eles, não há como olharmos de modo detido ao que Marx e Engels chamariam em 1845-46 (na Ideologia alemã) de concepção materialista da história. A crítica à religião e à política, portanto, levam nossos autores à compreensão do modo pelo qual os homens são o que fazem e como fazem; a análise da atividade humana sensível implica, ao contrário do que se dá em Feurbach, na compreensão da própria práxis, que ocorre em meio ao conjunto de relações sociais. Se não é o Estado o verdadeiro sujeito da sociedade, e não é o homem uma criatura divina, há de se analisar a produção e a reprodução dos próprios indivíduos socializados. E nunca é demais destacar que este continua sendo um grande tema marxiano até a sua morte, em 1883.

Não seria exagero, assim, dizer que Marx rompe com uma posição.

Porém, ela não é exatamente aquela de um grupo homogêneo - os neohegelianos, ou mesmo os neohegelianos de direita ou de esquerda -, mas aquela que se apoia na existência da sociedade civil-burguesa (a própria sociedade capitalista) como algo real e racional. Nosso autor passa - como ele diria explicitamente nos textos de 1844 (como os Manuscritos econômico filosóficos, por exemplo) - da crítica à religião, àquela da política e do Direito; da crítica da moral àquela dos pressupostos reais da economia política. Ele também deixa de ter esperanças no desenvolvimento do Estado político pleno na Alemanha (como ocorre, por 
exemplo, na Gazeta renana, em 1842). Em Sobre a questão judaica, ele diz que este Estado, bem como os direitos do homem, trazem consigo todas as mazelas contra as quais, aparentemente, os seus contemporâneos se contrapõem.

\section{RESGATANDO OS CLÁSSICOS: Em Sobre a questão judaica, Marx traça uma} diferença entre Emancipação Política e Emancipação Humana, qual a distinção? Essa distinção ainda é atual?

VITOR: Em Sobre a questão judaica, Marx mostra as limitações da posição de Bruno Bauer. Para o neohegeliano, a relação entre os indivíduos e o gênero humano estaria reconciliada por meio do Estado político pleno, dos direitos humanos e com a religião longe dos assuntos públicos. Há alguns aspectos a serem trazidos à tona sobe o tema.

Primeiramente, precisamos nos lembrar que a crítica de Marx vai da religião à política e desta à sociedade civil-burguesa. E, com isto, temos que a emancipação política é aquela que permanece nos marcos daquilo que nosso autor está criticando, ou seja, é aquela forma de emancipação que pode ser dar - com feições distintas dependendo da especificidade de cada país - no âmbito da sociedade capitalista (ou seja, da sociedade civil-burguesa). Neste sentido, a emancipação política certamente se caracteriza pelas esperanças colocadas na politicidade. Porém, a sua base é a sociedade civil-burguesa.

Neste sentido, segundo nosso autor, deixar de lado a oposição entre emancipação política e humana (bem como a relação entre revolução política e social) significa ater-se aos limites da sociabilidade vigente no presente. Ou seja, a crítica a esta contraposição, mesmo que seja colocada com tons mais ou menos progressistas e militantes, redunda em certa concepção que não deixa de remeter a um fim da história. Marx mostra que a na sociedade de seu tempo (que ainda é a nossa em suas determinações mais gerais) tem-se a base da religiosidade, da atomização dos indivíduos, da consideração destes indivíduos essencialmente como proprietários e da reconciliação destes aspectos mencionados com a política, o Direito e o Estado. Nosso autor demonstra como que uma crítica parcial a estes aspectos se caracteriza pela cegueira diante do fato de que, ao tratarmos do Estado, do Direito, da propriedade privada burguesa, bem como as sociedade capitalista, não se têm aspectos independentes, mas relacionados. E, por isto, a compreensão do presente implica no reconhecimento da correlação entre tais aspectos, que se reproduzem em conjunto, sendo necessário que se suprima todos eles para que se possa falar de uma sociabilidade superior àquela colocada na sociedade capitalista, e nas sociedades classistas como um todo. Por isto, Marx mostra a limitação da emancipação política, trazendo à tona - é verdade que com uma 
dicção que não será mantida em sua obra - a concepção de emancipação humana; nela, justamente, suprime-se estas determinações da sociabilidade burguesa como um todo, abrindo-se espaço para que a superação da oposição entre sociedade civil-burguesa e Estado por meio da supressão de ambos.

Outro aspecto essencial ao tema diz respeito ao fato de Marx - em contraposição a Bauer e aos seus consortes - não pensar a emancipação política, ou o Estado político como um ideal a se realizar. Em verdade, eles já estariam realizado e seriam efetivos na própria sociedade civil-burguesa, que lhes dá base real. Destaco tal aspecto porque não é raro que pesquisas sérias, como aquelas de Domenico Losurdo, Ellen Wood, entre outros destaquem o caráter bastante limitado do liberalismo e das revoluções burguesas.

Com base nisto, alguns poderiam pensar que sequer a emancipação política poderia ser realizada no capitalismo, de modo que a contraposição entre emancipação política e humana seria, de certo modo, idealista ou ultrapassada. Parece-me que a tal concepção falta o mínimo de compreensão sobre as críticas marxianas à religião, à política e à economia política. Em todas estas, nosso autor mostra que permanecer preso à oposição entre os pares antagônicos colocados nestes campos não leva numa posição crítica quanto à sociabilidade vigente. Antes, tem-se o oposto. Na religião, a relação entre o céu e a terra traz certa negatividade na medida em que a religião é o suspiro da criatura oprimida; mas, ao fim, a religião não nega a sociabilidade do presente e, por isto, também é uma espécie de ópio. A religião é um fruto de formas específicas de sociabilidade; ela eleva uma imagem invertida da sociabilidade presente ao reino dos céus. E, com isto, cria uma contraposição que não se explica pelo fato de a terra não ter chegado ao reino dos céus, mas na manutenção e reprodução da própria oposição entre céu e terra, sem a qual a religião (cristã, no caso) perde a sua base ideal. Na política, por sua vez, os diversos ideais de cidadania certamente opõemse às consequências da existência da sociedade civil-burguesa. Procuram uma participação na atividade comunitária, buscam elevar o interesse coletivo à estatura de algo universal, etc. Porém, Marx nos mostra que tal ideal, bem como os direitos do homem, são intimamente dependentes daquilo que criticam. Colocam-se como a outra face da própria sociedade cujas consequências critica. E, assim, seria preciso enfatizar que a consequência da emancipação política é ater-se aos limites da sociedade civil-burguesa, cuja conformação varia de país para país. Com isto, as bases da política - a propriedade privada, a atividade estranhada decorrente desta última, a oposição entre sociedade e Estado, a transfiguração da atividade humana em 
potências transcendentes como um deus, etc. - são efetivas, mesmo que a política pareça não ser.

Não podemos julgar o intelecto político pelo que diz de si, mas pelo que é.

Na primeira parte de Sobre a questão judaica, nosso autor demonstra como que o Estado laico e a consideração do indivíduo em uma dimensão universal, e não no particularismo de alguma religião, não supera a religião, nem a base desta. Cita, inclusive, como que nos EUA a religiosidade é extremamente forte, mesmo que o Estado seja laico. Trazer a religião como um assunto privado não implica em a influência da religião deixar de se colocar. Antes, tem-se o contrário até certo ponto. Na segunda parte do texto, há uma explanação de como a propriedade privada deixa de ser imediatamente decisiva no campo político. Com isto, não se emancipa os indivíduos diante da propriedade privada com a supressão em maior ou menor grau dos privilégios. Em verdade, emancipa-se a propriedade privada e coloca-se os indivíduos como se estivessem fechados sobre si mesmos. A cidadania, por sua vez, opõe-se aos sintomas de uma sociedade de proprietários. Porém, o processo pelo qual os indivíduos são reconhecidos como proprietários na sociedade - e não pelo seu nascimento, por exemplo - é o mesmo em que emerge o ideal de cidadania como uma potência ativa e real. Ou seja, nosso autor explicita como que a realização do ideal de cidadania está no bourgeois, assim como a realização do reino dos céus está na terra. E, na esteira do que ele já vinha trazendo em textos anteriores, como a Crítica à filosofia do Direito de Hegel, explicita-se como que o sujeito de tais oposições não está, respectivamente, no cidadão (no caso, no Estado) ou no Céu, mas no bourgeois (na sociedade civil-burguesa) e na terra.

Este é um passo muito importante no materialismo marxiano, que, como mencionei, implica na crítica à religião, à política e à sociedade civil-burguesa.

Com isto, chego a um ponto essencial, e um tanto quanto polêmico. Há em Marx, no período, e acredito que durante toda a sua obra, uma crítica à política e à religião como tais. Marx não está a criticar somente o cristianismo em Sobre a questão judaica. Ele mostra como que o universalismo do cristianismo não resolve as questões colocadas por Bauer ao tratar do judaísmo e da visão menos universal desta religião (que ainda se apoia no povo eleito, e não em uma concepção universal de pessoa); a posição marxiana é aquela segundo a qual as potências sociais estão estranhadas na religião, sendo preciso suprimir esta última e, com isto, reapropriar-se destas mesmas potências, para que usemos a dicção posterior de $O$ capital, de modo racional e comunitário. No caso da política, nosso autor demonstra - em diversos textos da época, mas também em seus últimos textos, como os assim chamados Manuscritos 
etnológicos - que sociabilidade e politicidade não se confundem. Demonstra que a política implica na oposição entre sociedade, potências sociais e Estado, sendo preciso abolir a política como tal.

No que eu gostaria de levantar um ponto sobre tal tema: a crítica à religião e à política não implica na indiferença diante destas. Digo isto porque estes são fatores muito importantes na compreensão da sociedade capitalista, sendo estes temas constantemente abordados tanto por Marx quanto por Engels. Levanto tal questão também porque há certas pessoas que, seja por ignorância, seja por má fé, criticam o filósofo brasileiro José Chasin por insistir neste ponto. Dizem que a crítica à política levaria à ausência de atuação no campo político, enquanto que, tanto para Marx quanto para Chasin, trata-se de, a partir da política, remeter às raízes sociais da sociedade civil-burguesa. Ou seja, longe de se ter certa preguiça ao se teorizar sobre a politicidade, deixando-a de lado, coloca-se um desafio gigantesco. Ele consiste pensar como que, a partir da sociabilidade burguesa, e das formas engendradas por ela, como a política do Estado moderno, é possível suprimir esta sociabilidade mesma. Isto passa pela ação política, mas não se resume a ela.

Devido ao que levantei anteriormente, acredito que a distinção de Marx ainda é muito atual. Não tanto devido a uma pureza de nomenclatura - nas obras posteriores de nosso autor, o tema aparece na correlação entre revolução política e social, por exemplo -, mas devido ao conteúdo essencial trazido à tona. Para ser muito direto: nossa esquerda, em grande parte, ainda não superou as posições de Bruno Bauer. Ou pior: por vezes, sequer é capaz de realizar uma crítica à religião com a radicalidade (limitada, é verdade) de um Bauer ou de um Feuerbach. Se pensarmos no Brasil, veremos certo apego - enorme, por vezes - à esfera política e temos também parte substancial de nossa esquerda com uma formação cristã. Se o pressuposto de toda a crítica é a crítica à religião, ainda estamos longe de conseguir chegar à real raiz de nossos problemas sociais. E, com isto, o voluntarismo da política parece ser resolutivo ao passo que, como sempre mencionava uma importante teórica chamada Lívia Cotrim, nunca poderia sê-lo. Enquanto se acreditar que é preciso realizar ideias, no caso, políticas, morais, ou religiosas, estamos perdidos. 
RESGATANDO OS CLÁSSICOS: Marx também faz reflexões sobre o caráter do Estado e do Direito em diferentes formações sociais (como a Prússia, Estados Unidos e Inglaterra) afirmando que a ausência de um Estado Político na Alemanha está atrelada ao problemas próprios da sociedade alemã, vocês podem traçar elementos da diferenciação entre sociedade e Estado para Marx nesse período de sua formação intelectual?

VITOR: Como mencionamos anteriormente, tal questão é decisiva para nosso autor. Em um texto da mesma época (As glosas marginais ao artigo do rei da Prússia), Marx diz que o intelecto político tem sua melhor expressão na França. Um pouco depois, ele analisa na Sagrada Família - este país, inclusive, ao tratar da expressão desta forma de intelecto em Napoleão Bonaparte. Ele vê o ímpeto francês como muito ligado ao Estado político que foi mencionado. Justamente, os revolucionários franceses (de 1789) procurariam dar as rédeas da sociedade civil-burguesa politicamente. E, com isto, há um impulso bastante sincero no sentido de se contrapor aos vícios da sociedade capitalista que se consolidava.

Porém, a função do ideal de cidadania, contraditoriamente, estaria justamente na efetividade da sociedade cujas consequências os revolucionários criticavam. Ou seja, aquilo que dissemos acima sobre a política e sua relação com a propriedade privada burguesa aparece em ato na formação social francesa. O resultado teria sido justamente um modo plebeu (ligado ao campesinato e aos pobres como um todo) de realizar os interesses da burguesia. Os revolucionários de 1789, portanto, acreditavam sinceramente que o Estado poderia, por meio do Direito (imbuído do Direito natural) colocar a sociedade como um predicado de sua atividade. Para que não nos alonguemos muito, vale dar um salto na explanação deste processo e mencionar que Napoleão traz algo distinto: ainda acredita na potência do Estado, mas, em verdade, já sabe que a base ineliminável sobre a qual ele se coloca é a sociedade civil-burguesa. Neste sentido, ao mesmo tempo, figura como um herdeiro da revolução e como alguém que não pode de deixar - tanto no plano ideal, quanto no prático - de enxergar como utópicos os ideais iniciais desta.

A França, portanto, traz consigo o intelecto político tanto em sua expressão mais radical quanto no reconhecimento dos limites da política. E, com isto, não é trivial que Marx tenha dedicado tantos escritos à França posteriormente. Se fossemos analisar o 18 Brumário de Luís Bonaparte, Luta de classes na França, Guerra civil na França, etc. fugiríamos muito de nosso tema, porém. Mas isto mostra como que a especificidade da formação social francesa trouxe muitos momentos de estudo para nosso autor. 
Para analisar isto, precisaríamos tratar da importância das revoluções de 1848 e, com isto, abordaríamos um período que ultrapassa em muito aquele que abordamos aqui.

Deste modo, acredito que é essencial mencionar que as declarações de diretos do homem que Marx analisa são aquelas da França e dos EUA. No caso do primeiro país, inclusive, nosso autor faz questão de analisar o período mais radical, aquele dos jacobinos, de 1793. Vale notar também que há importantes autores franceses, ou que foram muito lidos na França, que mencionados em Sobre a questão judaica. Representante da burguesia ascendente, Rousseau tem um importante papel, e o mesmo se dá com Toqueville. Este último, inclusive, é um importante analista da sociedade americana. No que diz respeito à política, portanto, precisamos voltar nossos olhos para a França, com certeza. Os EUA e a Inglaterra, porém, teriam um desenvolvimento até certo ponto similar àquele da França: estes três países possuíam uma classe burguesa que enxergava na emancipação política a realização de seus objetivos, de modo que neles se têm aquilo que poderíamos chamar de via clássica para o capitalismo. Claro, há distinções importantes entre eles, sendo a mais importante delas a instituição da escravidão nos EUA e dos pequenos camponeses na França. Porém, nestes países há a consolidação daquilo que seria o melhor dos mundos no que diz respeito ao modelo político burguês. E reitero: se há limitações claras na esfera pública destes países, isto não se deve a qualquer incompletude da emancipação política, mas porque os limites da política estão colocados nas bases da sociedade civil-burguesa. E, no caso americano, isto incluía a escravidão moderna. Ela não é qualquer resquício pré-capitalista, mas parte da formação social estadunidense, em que, como mencionamos, Marx aponta a existência do Estado político.

Um elemento importante para que compreendamos Sobre a questão judaica é este: não é a política e a cidadania aquelas capazes de ultrapassar as limitações da sociedade atual. O que é preciso é a transformação substantiva desta própria sociedade. Se é necessário passar pela política para isto, nosso autor sempre levanta ser importante a remissão para aquilo que figura como pressuposto da política, as bases reais da sociedade civil-burguesa. A política, assim, tem também um importante papel na teoria marxiana da época: ela procura dissolver as suas próprias bases, tendo-se aquilo que o filósofo brasileiro José Chasin chamou de metapolítica. Digo tudo isto porque as contradições que caracterizam a sociedade capitalista (e que precisariam ser suprimidas) são muito mais explícitas - em 1843-44 - em formações sociais como a estadunidense, a francesa e a inglesa. E o texto que aqui discutimos está 
questionando o Estado político como tal; e, por isso, debruçasse nestas sociedades que mencionamos, e não na sociedade alemã.

Falar da Alemanha seria aquilo natural a dois autores germânicos, como Marx e Bauer. Porém, não foi o que aconteceu em Sobre a questão judaica. Em primeiro lugar, porque isto não era o essencial ao texto do próprio Bauer, de certo modo. Ele discutia a situação dos judeus na Alemanha, porém, a compreensão de seu país e da especificidade do capitalismo em cada formação social acaba ficando em segundo plano diante do conceito de Estado e dos Direitos do homem. Como dissemos, isto é um reflexo do fato de a Alemanha ser contemporânea teórica das sociedades burguesas mais avançadas, mas não se colocar politicamente no mesmo patamar. Porém, isto nos traz um segundo ponto, que vem a ser de grande importância: a busca alemã pelo Estado político - ao contrário do que acontecia na França desde Napoleão - ainda trazia consigo muitas ilusões sobre as capacidades da política. Isto, como dissemos, foi visível no próprio Marx até 1842, em que, de modo similar aos seus colegas inspirados no conceito hegeliano de Estado, ainda apostava em uma esfera pública eivada pela universalidade do Direito e pela impessoalidade do Estado moderno. Se olharmos os textos da Gazeta renana, notaremos que os problemas da miséria alemã ocupam grande parte das linhas de nosso autor.

Os fatos de o localismo ainda imperar, de a propriedade fundiária ainda ser preponderante na economia alemã, de o Direito se colocar sob a forma do privilégio em diversos sentidos, etc. fizeram com que parecesse ser viável a defesa do Estado político para a resolução destes problemas. Posteriormente, Marx vê as ilusões desta posição.

Sobre a questão judaica, assim como Crítica à filosofia do Direito de Hegel, introdução, são textos essenciais justamente porque marcam uma ruptura decidida de Marx com tal posicionamento. Voltando os olhos para a sociedade civil-burguesa, nosso autor passa a ver como essencial apreender a especificidade de cada país para que se possa resolver de modo correto aquilo que ainda era visto de modo uma tanto quanto abstrato por Bruno Bauer e seus consortes. Uma explicação que não traz a diferença específica não é uma explicação, para que utilizemos aquilo que Marx disse já em sua crítica a Hegel.

RESGATANDO OS CLÁSSICOS: Para você, é importante o estudo dos textos do início da trajetória intelectual de Marx e Engels? Alguns teóricos marxistas apontam a existência de uma ruptura epistemológica entre o Marx da Juventude e o Marx da Maturidade, qual a opinião de vocês sobre proposição? 
VITOR: Parece-me ser essencial tal trabalho. Um dos temas mais discutidos no marxismo é a relação Marx-Hegel e, sem a compreensão do percurso formativo de nosso autor, principalmente, de seus textos da década de 1840, é impossível lidar com tal questão.

Por mais que a grande obra de Marx seja efetivamente $O$ capital, não há como desconsiderar tais textos, como Sobre a questão judaica, Glossas marginais, Manuscritos econômico-filosóficos, etc. Eu iria ainda mais longe: digo ser essencial para o desenvolvimento de um marxismo rigoroso e sério a leitura das obras de Marx em que ele ainda é explicitamente é idealista, como os artigos da Gazeta Renana, de 1842. Ali, e mesmo na tese doutoral - A diferença entre as filosofias da natureza de Demócrito e de Epicuro - é possível notar que nosso autor nunca foi estritamente um hegeliano, sempre trazendo uma posição crítica quanto ao sistema e quanto ao método deste autor. Mesmo que se inspirasse em Hegel, já trazia uma relação sui generis com tal autor. Tal modo de proceder, que Marx chamou de reflexo em sua tese, parece-me, ainda precisa ser estudado com mais cuidado. Sem isso, muitos ainda trazem uma compreensão demasiadamente hegeliana, principalmente sobre a obra econômica presente em $O$ capital, nos Grundrisse e nas Teorias do mais-valor. E, em verdade, grande parte dos temas que aparecem nestas obras já está presente nos textos da década de 1840. Tal questão, por assim dizer, filológica, não é meramente acadêmica, envolvendo elementos importantes, que dizem respeito à compreensão marxiana da crítica à religião, à política e à economia política.

Tal exagero na influência de Hegel - principalmente da Lógica hegeliana - é bastante visível em autores como Reichelt no exterior e Ruy Fausto por aqui.

E, deste modo, considero ser necessário estudar tais textos de Marx, não para aproximá-lo de Hegel, mas para que notemos como que, já neste momento, nosso autor critica de modo decidido o autor da Fenomenologia do espírito. Estudar a formação do pensamento de Marx é de grande relevo para que percebamos o modo pelo qual se desenvolvem suas críticas à especulação, à política e à economia política. Agora, é preciso que tomemos muito cuidado: seria loucura dizer que depois deste momento inicial da obra propriamente marxiana não há mais aquisições e mudanças em seu pensamento. Isto se dá tanto com Marx quanto com Engels, cujo texto Esboço para uma crítica da economia política, de 1844, é citado como "genial esboço" por Marx até o final de sua vida.

$\mathrm{E}$, neste sentido, podemos ver que os próprios autores não viam uma ruptura substancial de suas obras do começo da década de 1840 diante de suas aquisições posteriores (que, com certeza, são muitas). E, se mencionamos o exagero na aproximação de Marx com 
Hegel, temos também o oposto, a postura althusseriana que, a partir do conceito de corte epistemológico de Gaston Bachelard, procura extirpar qualquer problemática hegeliana do pensamento do autor de $O$ capital. Considero Althusser um pensador bastante sério e respeito muitos de seus discípulos, como, no Brasil, Márcio Naves, que pode ser considerado o principal expoente da crítica marxista ao Direito por aqui. Porém, acredito que o modo pelo qual o autor de A favor de Marx procede não faz jus à complexidade do texto marxiano. Ele está correto em apontar diferenças entre textos marxianos da década de 1840. Mas não acredito que exista ruptura e mudança de problemática posterior a obra Ideologia alemã. Existem diferenças, certamente, mas elas não justificam a crítica às obras anteriores como humanistas, idealistas, hegelianas, etc.

Se olharmos, por exemplo, para a categoria classe social, vemos que ela não cessa de se desenvolver na obra marxiana. Isto significa que o Manifesto seja um texto do "jovem Marx"? Parece-me que não. Ao olharmos a teoria do valor, notamos também que na Miséria da filosofia ela ainda não está madura. E também não está em seu formato final (se é que é possível falar em algo como um formato final...) nos Grundrisse, de 1857. Seriam estas obras desconsideradas pelos marxistas? Alguém sério dificilmente diria isto.

Há certa mania dos estudiosos de Marx de estabelecerem periodizações e cortes. Recentemente, chegou-se a falar que o "último" Marx teria superado as posições de $O$ capital e dos textos jornalísticos escritos sobre a China e a Índia. Também neste caso, acredito que tal pretensão não se sustenta, por mais que não deixe de existir aquisições importantes nos estudos marxianos sobre as comunas agrárias, sobre os diferentes "etnólogos", juristas e pensadores que trataram das sociedades sem classes, como Morgan, Maine, Maurer, Kovalevsky, etc. Algo que gostaria de deixar explícito é: o modo pelo qual é colocada a pergunta já denota o que aconteceu com os estudos sobre Marx em diversos sentidos. Muitos marxistas - diferentemente do próprio Althusser, acredito - deixam de lado o estudo dos textos do próprio Marx. Parece que ficam esperando ordens para saber o que devem e não devem ler de nosso autor. Tal posição é simplesmente lastimável. Com tal espírito de rebanho, não se vai muito longe.

Quero crer que todo o marxista deva estudar o máximo possível do próprio Marx, mesmo que nosso autor possa mudar de posição sobre determinadas terminologias (como a mencionada emancipação humana) e sobre temas como a lei do valor. Isto, claro, não significa que não devamos ler outros autores, mas, o mínimo que se exige de um marxista é o estudo criterioso de Marx. Gostaria de terminar a resposta a esta questão citando um marxista 
dos mais sérios que conheço, Elcemir Paço Cunha, professor da UFJF, para quem, para a esquerda, o rigor é um dever, e não uma simples opção.

RESGATANDO OS CLÁSSICOS: por fim, por que estudar Marx e ser marxista no século XXI? E quais textos indicam para revisitar a obra desse revolucionário, principalmente a produzida no início de sua trajetória intelectual e política?

VITOR: Um dos indícios da importância do pensamento de Marx é a sua permanência. Qualquer pensador sério ainda precisa, no mínimo, acertar as contas com nosso autor. E, tendo isto em mente, eu diria que se trata de um clássico. Sob este ponto de vista, tal qual Hegel, Weber, Keynes, trata-se de alguém que precisa ser lido. Porém, o estudo do pensamento marxiano é necessário também devido á atualidade de seu pensamento.

A compreensão das leis gerais do sistema capitalista de produção não foi feita por mais ninguém com tal rigor. Mesmo se olharmos para $O$ capital no século XXI, de Pikkety, e mesmo considerando a seriedade de tal economista, notamos que ele não trata de questões essenciais com o devido cuidado, como as classes sociais, por exemplo. Ou seja, ao estudar Marx, estamos sobre os ombros de gigantes. Ao nos apropriarmos de pensadores contemporâneos de modo acrítico, podemos estar nos baseando em teorias cujo alcance será ínfimo. Creio que aquilo que vem sendo chamado de marxologia, portanto, seja fundamental, embora, claro, não seja suficiente, para lidarmos com os desafios do presente. Deste modo, há uma justificativa importante da necessidade de se ler e estudar Marx, e ela está ligada à formação de qualquer indivíduo. Porém, há mais.

De certo modo, parte considerável da esquerda pretende se colocar para além de Marx. E, em verdade, fica muito aquém deste pensador. Se olharmos para Sobre a questão judaica, podemos dizer que o léxico da esquerda brasileira - só para que citemos um exemplo - aproxima-se muito da defesa dos direitos do homem, da cidadania, do Direito universal em oposição ao privilégio. Tal posição também pretende que o Estado tenha a capacidade de controlar a sociedade civil-burguesa, quando, em verdade, é preciso reconhecer que a relação é oposta: a estrutura da sociedade que engendra o terreno do Direito e o campo da política. Corro o risco de ser muito direto neste ponto, mas direi mesmo assim: talvez a esquerda contemporânea seja, na melhor das hipóteses, extremamente ingênua quanto às capacidades da política. Quando não é ingênua, é dotada de um cinismo de novo tipo, que acaba administrando os vícios da sociedade capitalista, deixando de lado qualquer perspectiva de 
transformação substancial da sociedade. Se isso é verdade, tal esquerda deixou de lado a própria crítica ao capitalismo e, neste sentido, pode-se concordar com José Chasin, que disse - muito antes do artigo de Vladmir Safatle - que tal esquerda está morta. E, por isto, talvez seja preciso que voltemos a Marx.

Isto é o mínimo que pode ser exigido. E, claro, não basta por si só. O marxismo não é um método mágico, mas uma tradição que se coloca no auxílio da apreensão aproximada das determinações da própria realidade. O escavamento cuidadoso dela implica no conhecimento de clássicos do marxismo, como Lênin, Lukács; mas também faz com que compreendamos, por exemplo, 1) a especificidade do capitalismo de cada formação social, 2) o papel distinto que a religião, o Direito e a política (só para que fiquemos nos principais temas de Sobre a questão judaica) cumprem em cada caso, 4) a posição de determinado país da divisão internacional do trabalho, 5) as tendências globais nas taxas de lucros, 6) a relação entre capital financeiro, especulativo, comercial e industrial, 7) a conformação das classes trabalhadoras no mundo e em determinadas formações sociais, 8) o grau de desenvolvimento das forças produtivas em seu sentido mais amplo, etc. Poderíamos citar muitas outras questões importantes para que compreendamos a realidade atual. Todas elas são de grande relevo e demandam muito trabalho - um trabalho coletivo, certamente - para serem esclarecidas com cuidado.

Caso não se compreenda tais aspectos ao menos de modo aproximado, continuaremos a entender a realidade por meio de jargões. E isto é a antítese direta do que Marx fez. Ser marxista no século XXI, tal qual no século XIX, implica em compreender o movimento da própria realidade para que se possa transformá-la de modo substantivo.

Se eu fosse trazer à tona alguns textos de Marx que são de uma atualidade gritante para auxiliar nestas questões que mencionei acima, diria que o livro III de $O$ capital tem um valor imenso. Em diversos artigos procurei tratar deste tema, de modo que aqui não irei me repetir. Porém, gostaria de apontar que figuras econômicas bastante cotidianas como custo de produção, juros, ganho empresarial, renda, dentre outras, são analisadas com muito cuidado por nosso autor. Elas fazem parte do cotidiano dos indivíduos que vivem na sociedade capitalista desde a época de Marx (se olharmos para o 18 Brumário, para as Lutas de classe na França, bem como para a Guerra civil na França, isto fica evidente). As pessoas se mobilizam em torno destes temas pois isto muda efetivamente as suas vidas, de imediato. Porém, é interessante notar como que a resolução destas questões não ocorre imediatamente por meio da política e do Direito, como colocaram aqueles que Marx chamou de socialistas vulgares. Ou seja, por mais que não possamos deixar de considerar tais pontos, não há como 
realizar uma crítica à sociedade contemporânea - ao menos uma crítica que seja digna de tal nome - se não se remete estas figuras econômicas, às formas econômicas da mercadoria, do dinheiro e do capital.

Ou seja, mesmo que não possamos deixar de nos posicionar, por vezes, política e juridicamente sobre tais temas, não há como resolvê-los a não ser pela modificação substancial das relações sociais de produção. Ninguém é louco em dizer que, em uma reintegração de posse, por exemplo, não seja necessário um advogado popular. Também seria muito quixotesco acreditar - com um jargão supostamente revolucionário - que tanto faz qual candidato vence uma eleição presidencial. Porém, há de se reconhecer que não é pelo advogado popular ou por meio de uma esquerda eleitoral (com um maior ou menor grau de cinismo) que se resolve qualquer coisa. A rigor, não se trata sequer de um uso tático do Direito ou da política em tais casos. Tem-se a necessidade de um posicionamento, mas isto não significa que se tenha possibilidades reais nestes campos.

Para que voltemos a nosso tema inicial, de certo modo, podemos dizer que Sobre a questão judaica, juntamente com as Glossas marginais, lança luz justamente sobre isto, sendo essencial a compreensão daquilo que Marx traz nestes textos. A leitura atenta dos textos da década de 1840 nos mostra um autor que sai das ilusões que são compartilhadas por parte substancial da esquerda contemporânea e é levado a uma crítica efetivamente radical. E, em minha modesta opinião, tal movimento é mais necessário que nunca.

\section{On Karl Marx in The Jewish Question}

Vitor Bartoletti Sartori

RESGATANDO OS CLÁSSICOS: Luís Eduardo da Rocha Maia Fernandes | Poliana Mendes Cavalheiro | Antonio Ugá Neto

How to cite this interview: SARTORI, Vitor Batoletti. Acerca de Karl Marx em Sobre a questão judaica. Resgatando os clássicos. Revista de Ciências do Estado. Belo Horizonte: v. 5, n. 1, e23740. ISSN: 2525-8036. 